\title{
The effect of addition of banana tree bark for compressive strength and crack tensile strength of rice husk ash concrete
}

\author{
Muhammad Rizqi ${ }^{1, *}$, Hernu Suyoso ${ }^{1}$, and Gati Annisa Hayu ${ }^{1}$ \\ ${ }^{1}$ University of Jember, Department of Civil Engineering, 68121 Jember - East Java, Indonesia
}

\begin{abstract}
The use of concrete as the main material in the construction does not mean it has no weaknesses. The brittle, low-density concrete properties make it collapse unexpectedly. In this work, a concrete innovation was performed to increase the compressive strength by the addition of rice husk ash as cement substitution that contains $92.31 \%$ of $\mathrm{SiO} 2$ and by the addition of banana tree bark. The proportion of rice husk ash used was obtained from preliminary tests to determine the proportion of rice husk ash by $5 \%, 7 \%, 10 \%, 12 \%$ and $15 \%$ of the cement's weight. The result of the proportion which yielded the optimum concrete compressive strength by $24.4 \mathrm{MPa}$ in the proportion of rice husk ash by $7 \%$, then was made with the same ash content with banana tree bark fiber variation $0 \% ; 1.5 \% ; 2 \%$ and $3 \%$. The Result of the test concluded that the addition of banana tree bark fiber can decrease the compressive strength and tensile strength of concrete because it is caused by the fibers that make hard concrete become solid. However, for all proportions of fiber, it still qualifies as the minimum tensile strength to be achieved i.e. $8 \%$ of the compressive strength of the plan.
\end{abstract}

\section{Introduction}

Concrete has a resistance to temperature effect (hydration heat), high acidity (Sulfate Resistance) and is resistant to corrosion. In addition, the weakness of concrete is that it is easily cracked or is brittle because it has a low ductility level, this is seen in the stress-strain curve of concrete where there is a rapid decline in the area after the peak load, causing a sudden collapse. [1] in his research to make concrete with the addition of fibers, concluded that the concrete has a very large push force, but the tensile strength of concrete is very low [2]. The use of Natural Fiber (natural fiber) is an option because of its availability in nature that can be renewed and is relatively cheap.

In Indonesia, one of the natural fibers that can be utilized as a concrete mixture is banana tree bark fiber, with a total production of banana trees in 2016 reaching 7.3 million tons [3]. According to previous research, banana tree bark has 5\% Lignin content, $63-64 \%$ Cellulose content, $20 \%$ Hemicellulose, while the mechanical properties of banana tree bark fiber have an average tensile strength of $600 \mathrm{MPa}$ and an average tensile modulus of 17.85

\footnotetext{
* Corresponding author: muhammadrizqi97@gmail.com
} 
GPa. Banana bark fiber diameter is $5.8 \mu \mathrm{m}$, while the fiber length is about $30.92-40.92 \mathrm{~cm}$ [4].

Another mixed material that can be used to improve the performance of concrete is rice husk ash, with a total rice production of 75.36 million tons of dry milled grain [5]. Rice yield will produce waste husk ash rice containing pozzolan material, that is silica ( $\mathrm{SiO} 2)$ equal to $92,31 \%$.

In this research, it will be made of structural fiber concrete with a mixture of rice husk as substitution material of cement and the addition of banana tree bark fiber so as to produce strong structural concrete to compressive strength and tensile strength, and to obtain fiber composition that yields optimal compressive strength.

\section{Material and methods}

The research was made by proportioning some concrete mixtures using banana tree bark fiber and rice husk ash. The research design will be implemented as in the table.

Table 1. Research design.

\begin{tabular}{|c|c|c|c|c|}
\hline \multirow{2}{*}{$\begin{array}{c}\text { Specimen } \\
\text { code }\end{array}$} & \multicolumn{2}{|c|}{ Proportion } & \multicolumn{2}{c|}{ Testing } \\
\cline { 2 - 5 } & $\begin{array}{c}\text { Rice Husk } \\
\text { Ash }\end{array}$ & Bark Fiber & $\begin{array}{c}\text { Compressive } \\
\text { Strength }\end{array}$ & $\begin{array}{c}\text { Crack Tensile } \\
\text { Strength }\end{array}$ \\
\hline NF & $\mathrm{x} \%$ & $0 \%$ & 7 & 7 \\
\hline FC1,5 & $\mathrm{x} \%$ & $1,5 \%$ & 7 & 7 \\
\hline FC2 & $\mathrm{x} \%$ & $2 \%$ & 7 & 7 \\
\hline FC3 & $\mathrm{x} \%$ & $3 \%$ & 7 & 28 \\
\hline \multicolumn{2}{|c|}{$\sum$ Number of Specimens } & 28 & \multicolumn{2}{c|}{56 Specimen } \\
\hline \multicolumn{3}{|c|}{$\sum$ total }
\end{tabular}

Ash husk ash content is the result of preliminary test of cylindrical concrete measurement $\varnothing 10 \mathrm{~cm} \times 20 \mathrm{~cm}$ with rice husk ash mixture which has the highest compressive strength value of some percentage which is made, then the result was used as substitution of cement in all proportion of fiber concrete.

In this study, mixing of concrete took place with rice husk ash as a substitute for cement and also banana tree bark fiber was added as an added material. In this research, the ash husk used it has been through a combustion process at a temperature of $550-800{ }^{\circ} \mathrm{C}$. The selected banana tree is banana tree type kepok originating from Lumajang, Eastern Java.

Prior to the planning, a preliminary test of the maximum proportion of rice husk ash used is used to produce a good compressive strength of concrete. Preliminary tests were also conducted on the feasibility of banana tree bark fiber including testing of tensile strength and weight-volume testing.

\subsection{Trial tensile test of banana tree bark fiber}

This feasibility test is conducted to determine the ability of fiber to be used as a mixture of fiber in concrete. This feasibility test is done by testing the tensile strength of banana tree fiber.

The stages performed are: the banana tree bark was cut so that it has a length of 500 $\mathrm{mm}$, then twisted to have a diameter of $18.9 \mathrm{~mm}$. Both ends are given a wire to clamp and then the test will be done with Universal Testing Machine. 


\subsection{Treatment of banana tree bark fiber}

Treatment performed on the banana stem is the separation of fiber and cutting of the banana tree bark. The stages are: separating the stem so that it becomes the sheets and then is separated from the fibers by removing the stem flesh. After the process, the drying is done to remove the water content in the fiber and then the fiber is cut with a length of $5 \mathrm{~cm}$ to be mixed in the concrete.

\subsection{Preliminary test of rice husk ash ash}

This preliminary test is conducted to determine the maximum proportion of rice husk ash as a cement substitution material for maximum compressive strength, which is then used as the proportion of the mixture of fiber concrete. Then the percentage of rice husk ash is determined to be $5 \%, 7 \%, 10 \%$ and $12 \%$ of the weight of cement. The test object used is a cylinder size $\varnothing 10 \mathrm{~cm}$ x $20 \mathrm{~cm}$ as much as 3 Samples of test specimen per proportion.

\subsection{Treatment of rice husk ash}

The treatment is done by observing the temperature of the furnace at the time of combustion in the tile-making industry using a Thermometer Furnace with Temperature being hinted to be at $550-800{ }^{\circ} \mathrm{C}$. Ash husk obtained was then pounded and sieving was performed to produce RHA that has a physical shape resembling cement, by passing it through 200 sieves.

\section{Results and discussion}

\subsection{Testing of banana tree fiber}

Testing of the banana tree bark fiber was performed to include weight volume and fiber tensile strength. It aims to be easy in analyzing the effect of added fiber as mixture concrete.

\subsubsection{Weight volume percentage}

To know the characteristics of banana tree bark fiber, then one of them is done by weight volume test

Table 2. Banana tree bark weight volume percentage.

\begin{tabular}{|c|c|c|c|c|}
\hline Testing Number & $\mathbf{1}$ & $\mathbf{2}$ & $\mathbf{3}$ & Unit \\
\hline Fiber Weight & 36,2 & 36,6 & 37,2 & gram \\
\hline Volume of Mold Cube & 125 & 125 & 125 & $\mathrm{~cm}^{3}$ \\
\hline Weight Volume & 0,2896 & 0,2928 & 0,2976 & $\mathrm{~g} / \mathrm{cm}^{3}$ \\
\hline Mean & \multicolumn{5}{|c}{0,293} & $\mathrm{~g} / \mathrm{cm}^{3}$ \\
\hline
\end{tabular}

Based on table 4:20 from laboratory testing, can be obtained data weight volume of banana tree bark fiber is equal to $0.293 \mathrm{~g} / \mathrm{cm}^{3}$. 


\subsubsection{Tensile strength of banana tree bark fiber}

From laboratory tests, the data of banana tree bark fiber with the diameter of $18,9 \mathrm{~mm}$ can be obtained, it has a tensile strength equal to $8,211 \mathrm{MPa}$ with a maximum force that can bear the load up to $2,304 \mathrm{KN}$ or $230,4 \mathrm{Kg}$ and increased fiber length by $9.33 \%$.

Table 3. Tensile strength of fiber.

\begin{tabular}{|l|c|c|}
\hline \multicolumn{1}{|c|}{ Result } & Value & Unit \\
\hline Initial Diameter & 18,9 & $\mathrm{~mm}$ \\
\hline Initial Length & 300 & $\mathrm{~mm}$ \\
\hline Tensile Strength & 8,211 & $\mathrm{MPa}$ \\
\hline Maximum Force & 2,304 & $\mathrm{KN}$ \\
\hline Final Diameter & 9,4 & $\mathrm{~mm}$ \\
\hline Final Length & 328 & $\mathrm{~mm}$ \\
\hline Elongation Percentage & 9,33 & $\%$ \\
\hline
\end{tabular}

The fiber tested has a shape like a rope that has a diameter of $18.9 \mathrm{~mm}$. The fiber behavior shown on the graph shows that the fiber has two melting points. At the first peak, the fiber decreases but can still carry the load until it reaches the second peak and the second peak is higher than the other one. The second peak is the final tensile strength of the banana tree bark that is equal to $8,211 \mathrm{MPa}$.

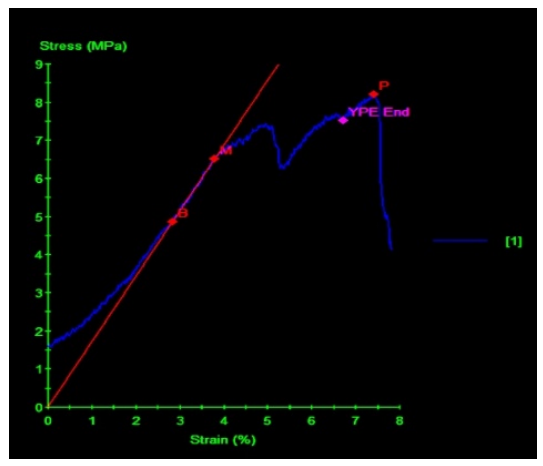

Fig. 1. Banana tree bark fiber tensile strength.

\subsection{Rice husk ash concrete preliminary test}

This concrete compressive strength test uses a cylindrical sized $\varnothing 10 \mathrm{~h} 20$. The test specimen of each proportion has a total of 3 pieces then the compressive strength value taken as the average value of the 3 specimens. Age of concrete to be tested is 7 days.

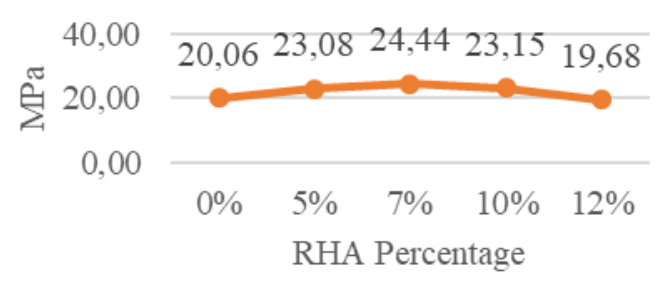

Fig. 2. Preliminary test of rice husk ash concrete. 
From the results of the rice husk ash concrete assay, a mixture of rice husk ash is proportionally assumed to be $7 \%$ in subsequent fiber concrete making. This is because the proportion of $7 \%$ is the maximum proportion of the use of added materials such as husk ash which can produce an optimal compressive strength of $24.44 \mathrm{MPa}$.

\subsection{Specimen test}

\subsubsection{Slump test}

The level of workability or slump value is closely related to the fas and the amount of water used. The more water used then the slump value generated will also be higher. The addition of water to the fiber concrete test specimen, given the same treatment as concrete without fiber. Provision of fiber in the concrete will certainly give effect to the value of slump generated.

Table 4. Slump test.

\begin{tabular}{|l|c|c|}
\hline \multicolumn{1}{|c|}{ Proportion } & $\begin{array}{c}\text { Water needed } \\
\text { from mix design }\end{array}$ & $\begin{array}{c}\text { Slump } \\
\text { (mm) }\end{array}$ \\
\hline 7\% RHA, 0\%Fiber & 0,371 & 62 \\
\hline $7 \%$ RHA, 1,5\%Fiber & 0,371 & 25 \\
\hline $7 \%$ RHA, 2\%Fiber & 0,371 & 10 \\
\hline $7 \%$ RHA, 3\%Fiber & 0,371 & 5 \\
\hline
\end{tabular}

The effect of adding fiber to slump value obtains linear graph with the equation $y=$ $19.893 x+57.827$ with correlation coefficient $(r)=0.9648$. With a value of $r$ close to 1 , it indicates that between the addition of fiber and the slump value there is a very strong relationship. The addition of fibers in the concrete causes the concrete mixture to get thicker and more difficult to work on. It can be concluded that the addition of fiber greatly affects the value of slump because the fiber is binding.

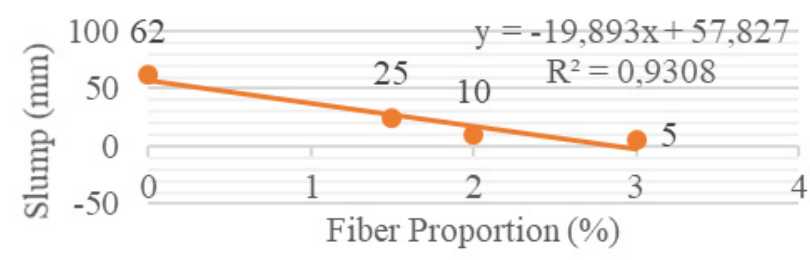

Fig. 3. Slump and fiber correlation.

\subsubsection{Weight of concrete fiber}

Based on the test results data that the addition of fiber can make the weight of the concrete content decrease because the weight of the contents closely relates to the level of concrete density. While the concrete density is determined by how easily the concrete is a solid and relates to the workability of the concrete. The more fiber is added, the lower the concrete density.

With each addition of fiber, the concrete continues to decrease the volume weight. Nonfiber concrete has a volume weight of $2576,75 \mathrm{~kg} / \mathrm{m}^{3}$, while concrete with $1.5 \%$ fiber content has a decreased volume weight of $2549,55 \mathrm{~kg} / \mathrm{m}^{3}$. For concrete with a fiber of $2 \%$ it 
has a volume weight of $2540,45 \mathrm{~kg} / \mathrm{m}^{3}$ and concrete with a proportion of $3 \%$ fiber has a volume weight of $2516,15 \mathrm{~kg} / \mathrm{m}^{3}$.

Table 5. Weight of concrete fiber.

\begin{tabular}{|l|c|c|}
\hline \multicolumn{1}{|c|}{ Proportion } & $\begin{array}{c}\text { Weigth } \\
\text { (Kg) }\end{array}$ & Weigth $\left(\mathbf{K g} / \mathbf{m}^{3}\right)$ \\
\hline 7\% RHA, 0\%Fiber & 4,0492 & 2576,75 \\
\hline 7\% RHA, 1,5\%Fiber & 4,0042 & 2549,55 \\
\hline 7\% RHA, 2\%Fiber & 4,0064 & 2540,45 \\
\hline 7\% RHA, 3\%Fiber & 3,9540 & 2516,15 \\
\hline
\end{tabular}

The effect of adding fiber to the weight of concrete obtains a linear graph with the equation $y=-19.951 x+2578.1$ with the value of correlation coefficient $(r)=0.996$. With a value of $r$ close to 1 , it indicates that between the addition of fiber and the slump value there is a very strong relationship.

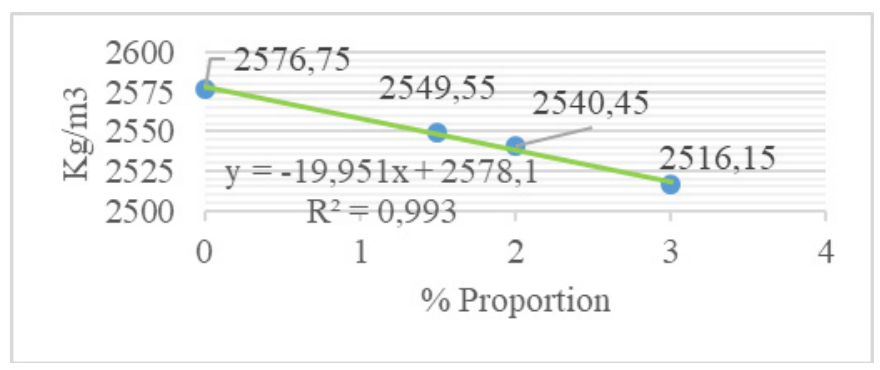

Fig. 4. Weight content and fiber correlation.

\subsubsection{Compressive strength}

From the compressive strength test, the value of concrete compressive strength decreased at each fiber variation. The proportion of husk ash without adding fiber produces a compressive strength of $25.175 \mathrm{MPa}$. Then for husk ash concrete with the addition of fiber equal to 1,5 it decreased by $15,4 \%$ from non fiber concrete and a has compressive strength equal to $21,302 \mathrm{MPa}$. In the $2 \%$ mixture of fibers, the concrete decreased by $19.3 \%$ and the concrete compressive strength to 20,327 MPa while for the concrete the proportion of fiber $3 \%$ experienced a very drastic reduction of $46 \%$ and had a compressive strength of 13,605 $\mathrm{MPa}$.

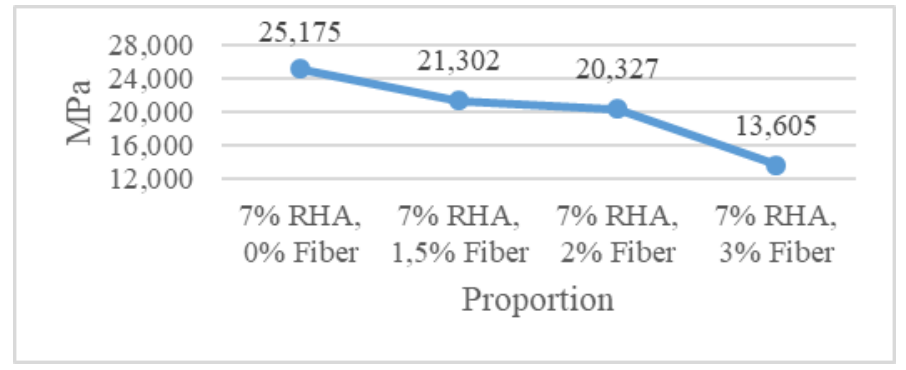

Fig. 5. Compressive strength.

The cause of the decrease in compressive strength is the difficult level of workability so that the concrete is difficult to compact. The better the level of workability, the better the 
compressive strength. Another thing that causes a decrease in compressive strength is from the weight of the concrete content. The weight of concrete fibers tends to be lighter than normal concrete because there is a cavity which is caused by the small level of workability. The higher the weight of the concrete content the higher the strength of the compressive strength.

Previous research, using rice husk ash as a cement substitution material, yielded an optimum compressive strength of $23.26 \mathrm{MPa}$. From this research, the optimum compression strength of $29.1 \mathrm{MPa}$ is obtained for the mixture of $7 \%$ rice husk ash and $0 \%$ fiber and the average is $25.17 \mathrm{MPa}$ and the addition of fiber in each variation can decrease the compressive strength.

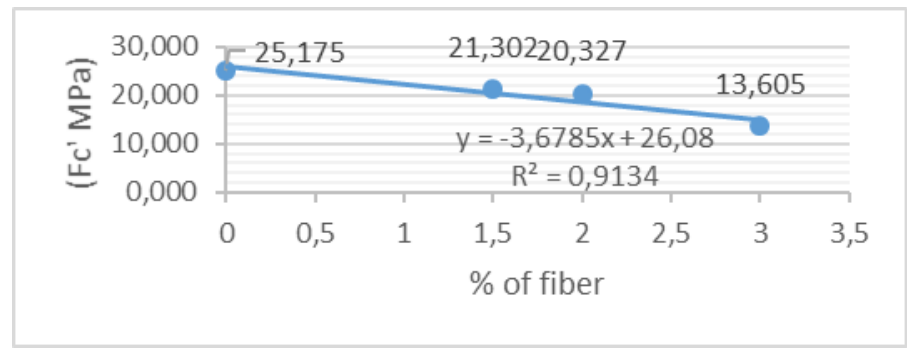

Fig. 6. Fiber and compressive strength correlation.

\subsubsection{Crack tensile strength}

From the Crack Tensile strength test, it was found that the value of tensile strength of concrete has decreased in the provision of fiber variations. The proportion of husk ash without adding fiber resulted in a tensile strength of 8,519 $\mathrm{MPa}$. Then for the husk ash concrete with the addition of fiber by $1.5 \%$ decreased by $2.6 \%$ of non-fiber concrete and has a tensile strength of $8.301 \mathrm{MPa}$. In the $2 \%$ mixture of fibers, the concrete also decreased the tensile strength of the previous proportion of $8.06 \mathrm{MPa}$ and decreased by $5.3 \%$ of its normal concrete. For concrete, the proportion of fiber 3\% decreased by $9.9 \%$ and has a tensile strength of 7,674 Mpa. From the tensile strength data, it can be concluded that the tensile strength of concrete has decreased but the optimum tensile strength for Concrete with the fiber mixture is found in the proportion of $1.5 \%$ fiber.

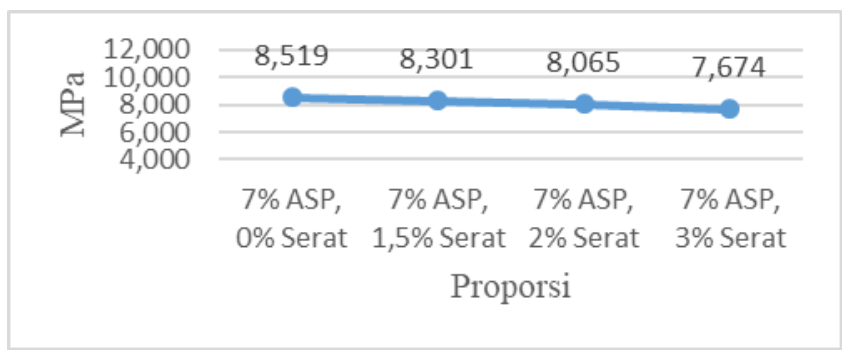

Fig. 7. Crack tensile strength.

The tensile strength of concrete usually ranges from $8-15 \%$ of compressive strength, then the minimum tensile strength to be met is $8 \%$ of compressive strength [6]. The compressive strength of concrete planned in mixed design is $25 \mathrm{MPa}$. So the tensile strength that must be met $(8 \%$ of $25 \mathrm{Mpa})$ is $2 \mathrm{MPa}$. The overall yielding tensile strength of all proportions can meet the specified limits even though the tensile strength of the concrete decreases. The tensile strength also decreases as well as the decrease that occurs in compressive strength, but for the decrease in tensile strength, it is not as much as the 
decrease in compressive strength. With value $r=0,96203$, the value of $r$ is based on the interval table can be concluded that between the addition of fiber to the drop of tensile strength there is a strong relationship.

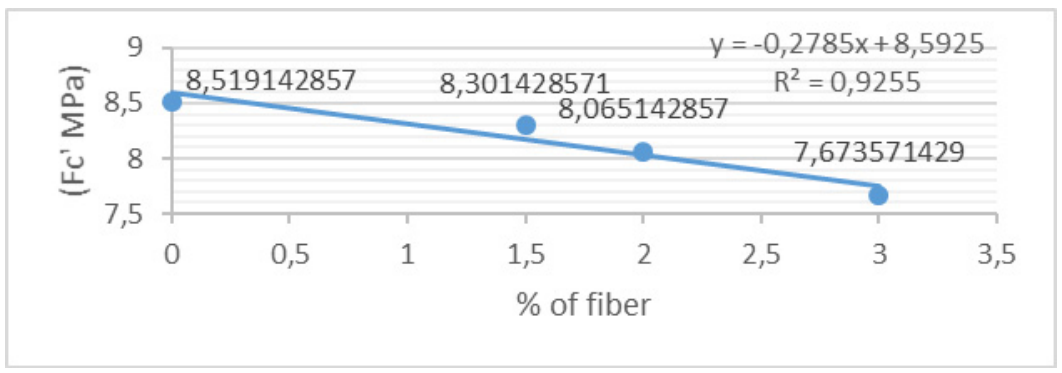

Fig. 8. Fiber and tensile strength correlation.

\section{Conclusions}

This experimental study was to present the ratio of adding fiber as a concrete mixture of rice husk ash. Rice husk ash which we know contains silica (SiO2) of 92.31\% and can improve the compressive strength of concrete. It is proven from the preliminary test results of rice husk ash making which has a compressive strength of $24.4 \mathrm{MPa}$ in the proportion of rice husk ash by $7 \%$. Banana tree fibers can also be used as a concrete mixture having a tensile stress of $8.2 \mathrm{MPa}$.

The effect of the percentage of banana stem fiber on concrete strength and tensile strength of concrete was $7 \%$ rice husk ash and $0 \%$ fiber yielding compressive strength of $25,175 \mathrm{MPa}$ and tensile strength of $8,519 \mathrm{MPa}, 7 \%$ rice husk ash and $1.5 \%$ fiber yielding compressive strength of $21,302 \mathrm{MPa}$ and tensile strength of $8,301 \mathrm{MPa}, 7 \%$ rice husk ash and $2 \%$ fiber yielding compressive strength of $20,327 \mathrm{MPa}$ and tensile strength of 8,065 $\mathrm{MPa}$ and 7\% ash husk rice and 3\% fiber yielding compressive strength of $13,605 \mathrm{MPa}$ and tensile strength of $7,674 \mathrm{MPa}$.

It can be concluded that the addition of banana tree bark fiber can decrease the compressive strength and tensile strength of concrete because it is caused by the fibers that make hard concrete become solid and the decrease of compressive strength and tensile strength is directly proportional to the weight of the contents. The lower the weight of its contents, the more it goes down the compressive strength. However, for all proportions of fiber, it still qualifies as minimum tensile strength to be achieved i.e. $8 \%$ of the compressive strength of the plan.

\section{References}

1. Wilhelmus. The Effect of Gewang Leaf Fiber Addition (Corypha Utan lam) for Flexural Strength and Crack Tensile Strength of Concrete. Kupang. Civil Engineering Department Nusa Cendana University. (2015)

2. V. G. Ndoen, D. A. T. Sina, W. Bunganaen. Effects of additional fiber leaf (corypha Utan lam) on strong and powerful strength Concrete. Civil Eng. 4, 14 (2015)

3. Suwandi, N. Leli, W. Budi. Agricultural commodities in the field of horticulture. Ministery of Agriculture. ISSN 1907-1507. 68 (2016)

4. Nopriantina, et al. Effect of Kepok Banana Leaf Thickness (Musa paradisiaca) To the Mechanical Properties of Natural Fiber-Polyester Composite Materials. Padang. Physics Department of FMIPA Andalas University. (2013) 
5. S. C. P. District. Pasirian District in numbers. Statistic Agency. 35080.1605, 118 (2016)

6. Rahmatullah D. Making of structural concrete by using skoria stone and plastic seed. Departement of Civil Engineering, University of Jember (2017). 